\title{
Effect of plant growth regulators and nitrogenous compounds on seed germination of pepper (Capsicum frutescens $\mathrm{L}$ )
}

\author{
${ }^{* 1}$ EREMRENA, PO; ${ }^{2}$ MENSAH, SI \\ Department of Plant Science and Biotechnology, Faculty of Science, University of Port Harcourt, P.M.B. 5323, \\ Choba Port Harcourt, Rivers State, Nigeria. \\ Corresponding author email: peter.eremrena@ uniport.edu.ng
}

\begin{abstract}
The seed germination of Capsicum frutescens $\mathrm{L}$. was investigated through various methods, namely, washing and air dry storage treatments, applications of gibberelic acid $\left(\mathrm{GA}_{3}\right)$, Kinetin, potassium nitrite $\left(\mathrm{KNO}_{2}\right)$ and potassium nitrate $\left(\mathrm{KNO}_{3}\right)$ to improve germination of seeds in view of poor germination reported. The seeds were subjected to the following treatments namely washing to remove the slimy coverings; air-drying at various time-intervals; incubated in different concentrations of $\mathrm{GA}_{3}$, Kinetin, $\mathrm{KNO}_{2}$ and $\mathrm{KNO}_{3}$. The treatments were subjected to light or dark germinations at $30^{\circ} \mathrm{C}$ and radicle emergence scored after 15 days. The various results showed that washing treatment, and light germination had a significant effect on the germination of Capsicum frutescens seeds. For air-drying treatment, germination increased from 0-48hrs and decreased after $72 \mathrm{hrs}$, 48hrs air-drying duration gave the highest percentage germination. Application of $\mathrm{GA}_{3}$, kinetin, $\mathrm{KNO}_{2}$ and $\mathrm{KNO}_{3}$ in low concentrations promoted the germination of freshly harvested Capsicum frutescens seeds. Generally the $\mathrm{KNO}_{2}$ and $\mathrm{KNO}_{3}$ gave the best germination results. The findings of this study have significant implications in the commercial production of Capsicum frutescens in view of its economic and medicinal importance. CJASEM
\end{abstract}

\section{http://dx.doi.org/10.4314/jasem.v20i2.3}

Keywords: Growth regulators, Nitrogenous compounds, Capsicum frutescens.

The genus Capsicum frutescens comprises more than 200 varieties, and the fruits vary widely in size, shape, flavour and sensory heat. Five main species are cited in literature: Capsicum annum, Capsicum baccatum, Capsicum chinense, Capsicum frutescens and Capsicum pubescens. Peppers from Capsicum species are native to the tropical and humid zones of Central and South America and belong to the Solanaceae family (Zimmer et al., 2012). There are many local cultivars grown in West Africa. Nigeria alone has more than 200 selections of pepper (Idowu-Agida et al., 2012).

The habits and habitats of Capsicum frutescens have been extensively described in various literatures. It is an annual or short-lived perennial herb with height of 1-4 feet; leaves are elliptical, dark green and smooth, and measures $2 \frac{1}{2}$ inches long and 1 inches wide; the flowers are typically conical or funnel form; the fruits are erect, ellipsoid conical to lanceoloid, $10-20 \mathrm{~mm}$ long, $3-7 \mathrm{~mm}$ in diameter; while the fruits range in colour from green when immature to purple, red, orange or yellow when ripe (Kirtikar and Basu, 1980; Menhichini et al., 2009).

One of the problems that farmers face is the germination of pepper seed, that even under favourable conditions, is slow and uneven, thus suggesting the existence of a certain type of dormancy in seeds of these species (Edwards and Sundstrom, 1987), which justifies the use of methods which help to accelerate the process of germination and uniform emergence in the field. Among the chemicals that are used for rapid and uniform seed germination are the plant growth regulators and biostimulants that control metabolism and the responses of seeds to the environment (Davies, 1994).

Capsicum frutescens is widely used as food flavouring agent, a colouring agent, an additive in livestock feed and pharmaceutical industries; excellent sources of various antioxidant compounds like flavonoids, carotenoids and vitamin $\mathrm{C}$; fruits contain capaiscin which is used in modern medicine as a circulatory stimulant, pain reliever and an aerosol extract of capsaicin (pepper spray) are used by the police as nonlethal means of incapacitating a person (Boonkird et al., 2009; Zhuang et al., 2012; Oboth and Rocha, 2007).

It is believed that biostimulants, depending on the composition, concentration and proportion of substances, can increase plant growth, stimulating cell division, as well as increasing the absorption of water 
and nutrients for plants. The pre-soaking in plant growth regulators and biostimulants solutions can influence seed germination by accelerating the whole processes, which starts with the absorption of water, ending with the embryonic axis elongation (Bewley et $a l ., 2013)$. Studies performed in order to increase the germination of seeds of peppers (Fialho et al., 2010), testing the effect of priming in seeds of yellow-longpepper-(Capsicum annum L.) and the use of various chemical treatments, including moistening of the substrate with gibberellic acid, amnociclopropene 1carboxylic acid, polyethylene glycol, $\mathrm{KNO}_{3}$ and precooling for rapid and uniform germination of seeds of true-cumari-pepper (Capsicum baccatum var. Praetermissum L.).

Reports of promotory effects in dormancy breaking and enhancement of seed germination of some of these treatments and chemical substances for other species have been noted (Hsiao, 1979a; 1979b; Onofeghara, 1981; Nzegbule and Mbakwe, 1999; Tambari and Aminu, 2015; Al-Menaie, 2010; Ramamoorthy, 2005; Irfan et al, 2013; Ajiboye, 2010). The germination of Capsicum frutescens seeds, even under favourable conditions, is slow and disuniform and freshly sown seeds undergo rapid decay (Ado, 1987). These findings implied unavailability of the seeds in required quantity and at required time. Thus there is need to ensure continuous availability of this valuable plant species. Reports on the seed germination of Capsicum frutescens have been lacking or few in between. This study therefore intends to identify treatment methods to enhance germination of Capsicum frutescens in view of its economic, medicinal and agricultural potentials and uses.

\section{MATERIALS AND METHODS}

Source of Seeds: The matured fruits of Capsium frutescens seeds were harvested from Agricultural Development Programme (ADP) Rumuodomaya, Rivers State. Fresh fruits which had not under gone any decay were collected and used for the experiment.

Viability Test: The Triphenyl tetrazolium chloride test (TTC) as developed by Lakon (1949) was used. The test is based on the understanding that living seed releases hydrogen molecules as a result of the action of dehydrogenase enzymes. The hydrogen molecules so released reduced the oxidized colourless form of TTC to formazan-red colour. Seeds were split longitudinally through the embryo and soaked in 5\% solution of 2,3,5- Triphenyl tetrazolum chloride (TTC), then left for 2 hours in the dark. The embryonic region was then examined for accumulation of formazan by noting the amount of red colour. The embryonic sections of the seeds were coloured formazan red, indicating viability and were used for the experiment.

Treatment Methods: Washing: Germination of unwashed and washed seeds were examined to determine if the slimy coverings on the seeds impede germination. Unwashed and washed seeds were germinated as described under the germination conditions.

Dry storage at Room Condition: The seeds of Capsicum frutescens were stored at room condition for various time-intervals ranging from 0hours, 12hours, 24hours, 36hours, 48hours, 60hours and 72hours. After each storage time, seeds were subsequently germinated at required temperature. The objective of such treatment was to find out if germination increases or decreases with dry storage period. The seeds that germinated were counted on daily basis for 15 days.

Gibberellic Acid and Kinetin Treatments: The effect of gibberellic acid and kinetin on the germination of Capsicum frutescens was investigated. The different concentrations applied were $3.5 \mathrm{mg} / 1,35 \mathrm{mg} / \mathrm{l}$ and 346 $\mathrm{mg} / \mathrm{l}$ for $\mathrm{GA}_{3}$, and $2 \mathrm{mg} / \mathrm{l}, 22 \mathrm{mg} / \mathrm{l}$ and $215 \mathrm{mg} / \mathrm{l}$ for kinetin. For each of the treatment, a control experiment was always set up alongside.

$\mathrm{KNO}_{3}$ and $\mathrm{KNO}_{2}$ Treatment: The effects of potassium nitrate and potassium nitrite on the germination of Capsicum frutescens were also investigated. The different effects of concentrations, namely $101 \mathrm{mg} / \mathrm{I}$, $505 \mathrm{mg} / \mathrm{l}$ and $1010 \mathrm{mg} / \mathrm{l}$ of potassium nitrate $\left(\mathrm{KNO}_{3}\right)$ and $85 \mathrm{mg} / 1,425 \mathrm{mg} / \mathrm{l}$ and $850 \mathrm{mg} / \mathrm{l}$ of potassium nitrite $\left(\mathrm{KNO}_{2}\right)$ were examined.

Germination Procedures: For each treatment carried out, four replicates of 20 seeds per replicate were put in a $9 \mathrm{~cm}$ plastic petri dishes, lined with $9 \mathrm{~cm}$ Whatmann Filter paper, moistened with $3 \mathrm{mls}$ of distilled water or the required chemical solution and germinated at $30^{\circ} \mathrm{C}$. Germination was monitored for a period of 15days and radicle emergence was scored as an index of germination.

Statistical Data Evaluation: All data collected were subjected to statistical analysis such as Analysis of variance (ANOVA) and standard error means. New Duncan Multiple Range Test (NDMRT) was employed to separate means.

\section{RESULTS AND DISCUSSION}

Washing Treatment: The percentage germination for washed and unwashed seeds was $35 \%$ and $16 \%$ 
respectively after 8days of incubation in the dark. At the end of the experiment i.e. 15dys of incubation, percentage germination increased to $58 \%$ for washed and $52 \%$ for unwashed (Fig. 1). The rate of percentage germination was enhanced in the washed seeds over the unwashed (control). The unwashed seeds may have some substances that may inhibit the percentage germination. Light promoted the germination of Capsicum frutescens seed in both washed and unwashed treatments. The rate of percentage germination for washed seeds is significant over the control (unwashed) at $\mathrm{P}=0.05$. Many seeds require light for germination to occur more rapidly e.g. seeds of Betula pubescens and Pinus sylvestris which germinates more rapidly if exposed to light. Seeds sown on the surface of the soil or lightly covered with soil germinated more rapidly (4days) than those kept in the dark or planted in the deep (8days), (Jeffrey, 2005). The promotion of germination might be phytochrome controlled, that is red light promotes while far red light inhibits

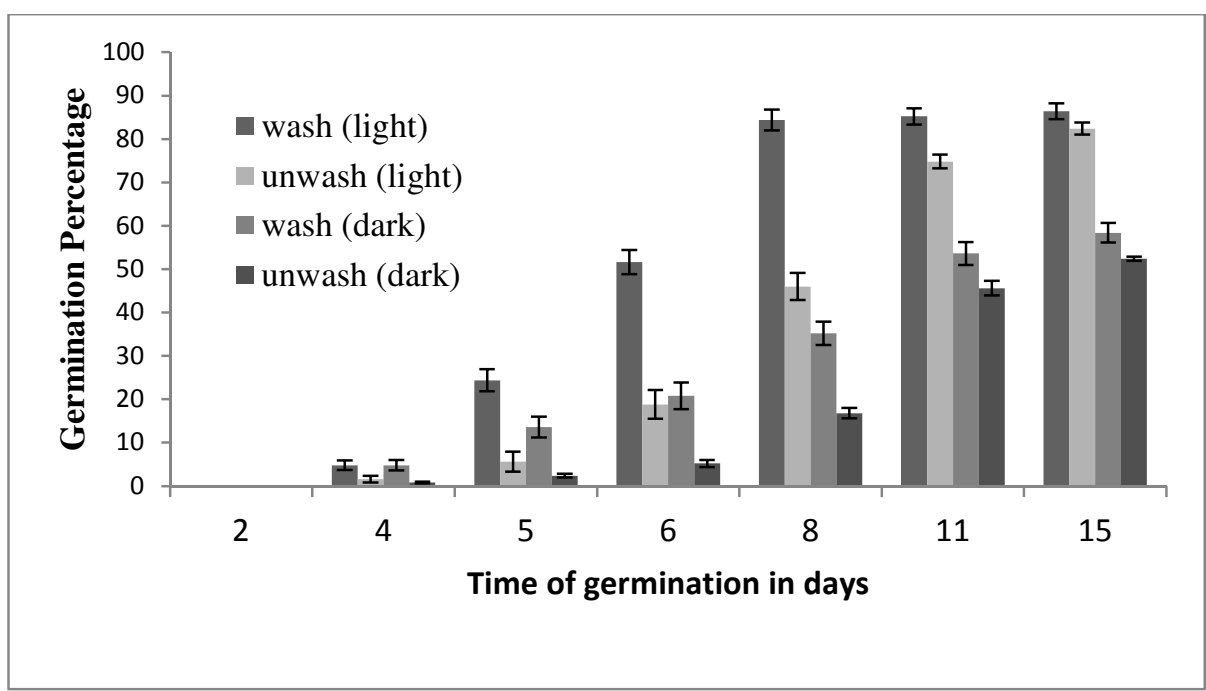

Fig.1: Effect of Light illumination and darkness on the germination of washed and unwashed seeds of $C$. frutescens germinated at $30^{\circ} \mathrm{C}$

Dry Storage Treatment: The result of dry storage at room temperature $\left(30^{\circ} \mathrm{C}\right)$ shows that the percentage germination gradually increases from $0 \mathrm{hr}$ to $48 \mathrm{hrs}$ and then gradual decreases after $72 \mathrm{hrs}$ air-dry storage (Fig. 2 ). The best time for drying was $48 \mathrm{hrs}$, which gave the maximum percentage germination. The maximum percentage germination (48hrs) was not significant over the control at $\mathrm{P}=0.05$. Also, drying the seeds at different intervals did not significantly increase the percentage germination.

Ecologically, the effect of high temperature in the soil might act to produce drying in the soil, and may impose or release dormancy. In the laboratory, this process is stimulated by keeping dry seeds at elevated temperatures in the range of $35^{\circ} \mathrm{C}-50^{\circ} \mathrm{C}$ and is a form of "after-ripening". It is regarded as any change which occurs in the seeds during storage as a result of which germination is improved (Evenari, 1965), however, in some cases, long storage drying could also impose dormancy e.g. in lettuce seed (Nutile, 1945), decreased germination in Traculia africana after two weeks of storage. (Dolor, 2013). In this study, storage up to $48 \mathrm{hrs}$ enhanced germination. The resultant effect of "after-ripening" process is to widen the conditions under which dormancy can be broken and germination expressed. 


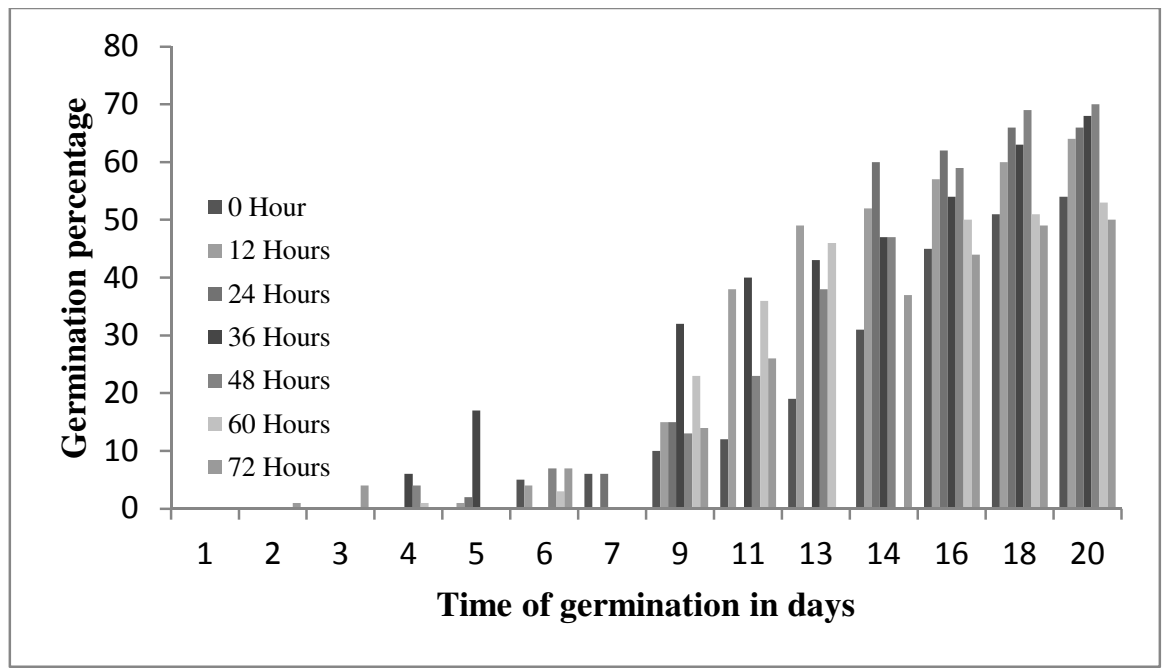

Fig. 2: The Mean percentage of seeds unwashed and kept dry at various time intervals (hrs) germinated at $30^{\circ} \mathrm{C}$

$G_{3}$ Treatment: Treatments with the 3 different concentrations of Gibberellic acid $\left(\mathrm{GA}_{3}\right)$ increased germination percentage over the control. $3.5 \mathrm{mg} / \mathrm{l}$, $35 \mathrm{mg} / \mathrm{l}$, and $346 \mathrm{mg} / \mathrm{l}$ treatments gave germination percentages of $80 \%, 81.25 \%$ and $87.5 \%$ respectively, while the control gave $60 \%$ (Fig. 3). The percentage germination was not significant when compared to the $346 \mathrm{mg} / 1$ treatment and the control at $\mathrm{P}=0.05$. These results agreed with those of Mohammed (2007) in bean and Jamil and Rha (2007) in sugar beet. The stimulatory effect of gibberellic acid on germination percentage and seedling growth has been also reported in wheat (Akman, 2009). In fact, exogenous gibberellic acid causes an increase in germination and seedling growth by enhancing the availability of endogenous gibberellic acid (Kauer et al., 1998). This could be explained by the fact that $\mathrm{GA}_{3}$ may reduce the abscisic acid level in seeds through the activation of their catabolism enzymes or by blocking the biosynthesis pathway (Toyomasu et al, 1994). It has been reported by other researchers that Gibberellic acid $\left(\mathrm{GA}_{3}\right)$ is successful in ending dormancy in numerous species of seeds and also in accelerating the germination of non-dormant seeds. Effective concentrations generally lie within the range $0.10-$ 10mM (Joshi, 1979).

Gibberellins have also been demonstrated in the control of the production of hydrolytic enzymes that ultimately lead to hydrolysis of seed food reserves and promoting germination (Paleg, 1965; Radley, 1967). In the endosperm of castor bean (Ricinus communis) seedlings, $\mathrm{GA}_{3}$ stimulated the activities of at least 16 enzymes involved in gluconeogenesis, and the process of seed germination (Gonzalez and Delsol, 1981).

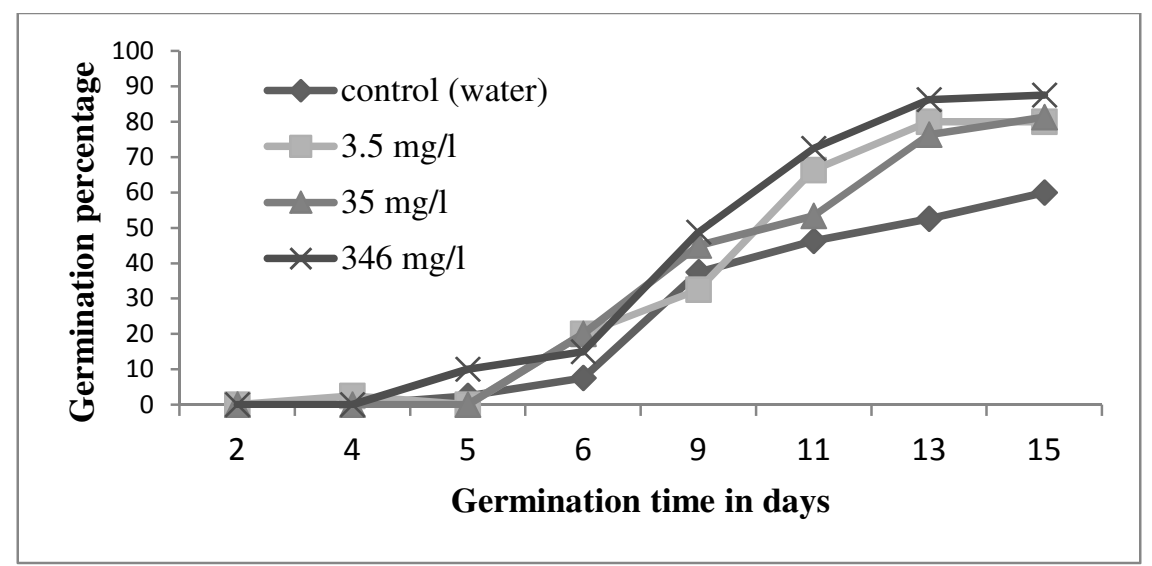

Fig.3: Effects of 3.5mg/l, 35mg/l, and $346 \mathrm{mg} / \mathrm{l}$ concentrations of Gibberellic acid on C. frutescens seeds germinated at $30^{\circ} \mathrm{C}$ 
Kinetin Treatment: The results revealed the physiological response of Capsicum frutescens to kinetin at different concentrations. $2 \mathrm{mg} / \mathrm{l}, 22 \mathrm{mg} / \mathrm{l}$ and $215 \mathrm{mg} / \mathrm{l}$ treatments gave germination percentage of $78.8 \%, 80 \%$ and $90 \%$, respectively, while the control gave $55 \%$ (Fig.4). $215 \mathrm{mg} / \mathrm{l}$ gave the highest percentage of $90 \%$. The percentage germination were not significant when compared to the $215 \mathrm{mg} / \mathrm{l}$ treatment and the control at $\mathrm{P}=0.5$. The trend of germination promotion was in accordance with those reported for Arachis hypogeal (Ketring and Morgan, 1971), Cajanus cajan (Mehta, 1978), and Zea mays (Bhatnagar and Rastogi, 1980). The mechanism by which kinetin promotes germination is not well understood. In Phaseolus vulgaris seeds incubated for four days, cytokinin released by the embryonic axis of seeds regulate the activity of a number of hydrolyzing enzymes which occur in the cotyledon (Van Staden et al., 1982., thus promoting germination

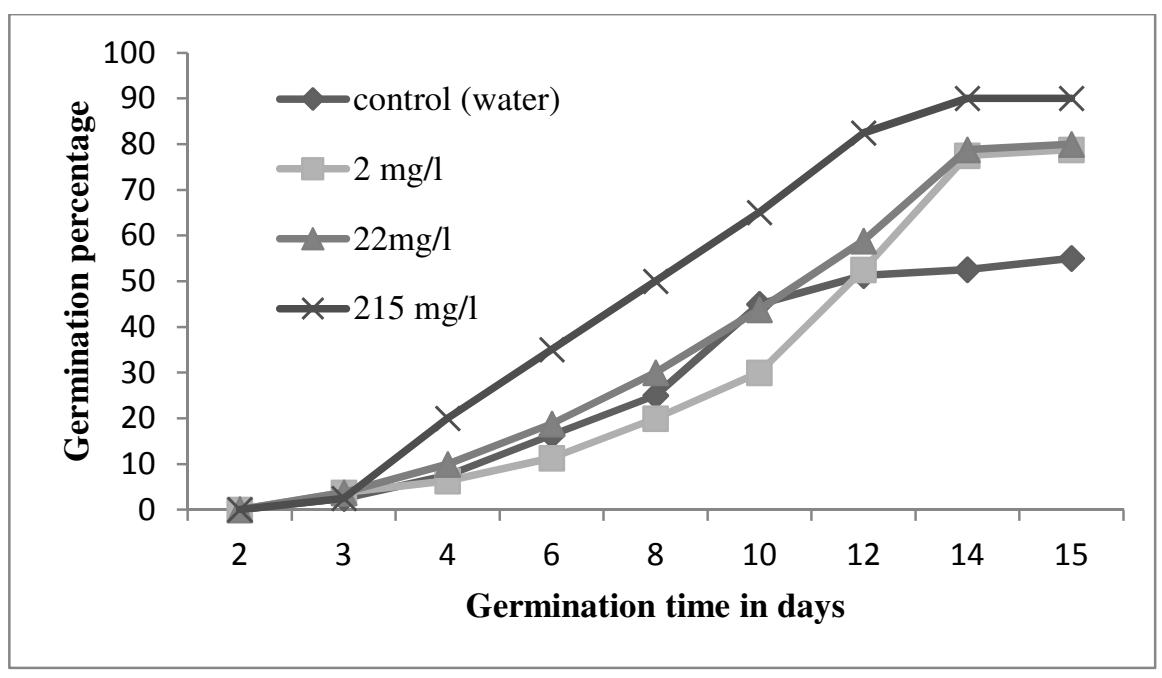

Fig.4: Effects of $2 \mathrm{mg} / \mathrm{l}, 22 \mathrm{mg} / \mathrm{l}$ and $215 \mathrm{mg} / \mathrm{l}$ concentrations of kinetin on $C$. frutescens seeds germinated at $30^{\circ} \mathrm{C}$

$\mathrm{KNO}_{2}$ Treatment: The mean percentage germination of seeds treated with $85 \mathrm{mg} / \mathrm{l} \quad \mathrm{KNO}_{2}$ improved germination percentage over the control. $85 \mathrm{mg} / \mathrm{l}$ $\mathrm{KNO}_{2}$ gave the highest percentage germination of $81 \%$ while the control was $60 \%$ (Fig. 5). However, as the concentration of $\mathrm{KNO}_{2}$ increases, the germination percentage decreases $425 \mathrm{mg} / \mathrm{l}$ and $850 \mathrm{mg} / \mathrm{l}$ gave percentage germination of 55\% and 53\% respectively (Fig. 5). There was no significant difference between the control and $85 \mathrm{mg} / \mathrm{l}$ treatments even at $5 \%$ level of probability.

$\mathrm{KNO}_{3}$ Treatment: The $101 \mathrm{mg} / \mathrm{l}, \quad 505 \mathrm{mg} / \mathrm{l}$ and $1010 \mathrm{mg} / \mathrm{l}$ treatments with $\mathrm{KNO}_{3}$ gave germination percentages of $84 \%, 79 \%$, and $61 \%$ respectively while the control was $58 \%$ (Fig. 6). $101 \mathrm{mg} / \mathrm{l}$ treatment gave the highest percentage germination.

$\mathrm{KNO}_{3}$ stimulates germination at low concentrations, but inhibits at higher concentrations. The percentage germination was significant when compared to the $101 \mathrm{mg} / \mathrm{l}$ treatment and the control at $\mathrm{P}=0.5$. These results seem to agree with the postulation of Mayer and Poljakoff - Mayber (1989) that nitrogenous compounds such as nitrate and nitrite stimulate the germination of many seeds. Potassium nitrate and nitrite solution has long been known as a suitable chemical approach for promoting germination in various plant species and generally as a priming agent in germination media (Argerich and Bradford, 1989; Bush et al., 2000; Madakadze et al, 1993; McDonald, 2000; Tambari and Aminu, 2015; Al-Menaie, 2010; Ramamoorthy, 2005; Irfan et al, 2013; Ajiboye, 2010; Faezeh and Vajihe, 2014; Hendricks and Taylorson, 1975; Roberts, 1973).

It has been speculated that these chemicals function to promote pentose phosphate (PP) pathway (Hendricks and Taylorson, 1975), and nitrate may functions by being reduced to nitrite or hydroxylamine and the hydroxylamine ions formed might be coupled to a respiratory chain which promotes germination through cyanide - resistant respiratory activity (alternative pathway). However, Eashi et al (1979) rejected the hypothesis that nitrates and nitrites promoted germination by inhibiting catalase actions because $\mathrm{KNO}_{2}$ and $\mathrm{KNO}_{3}$ inhibited catalase activity but were ineffective in stimulating the germination of 
unimbibed (dry) seeds of cocklebur. Juntila and Nilsen (1980) noted that respiratory intensity is not correlated with germination of Phalaris arundinacea. It can be concluded that the mechanism of action of $\mathrm{KNO}_{2}$ and $\mathrm{KNO}_{3}$ in promoting germination needs further investigation.

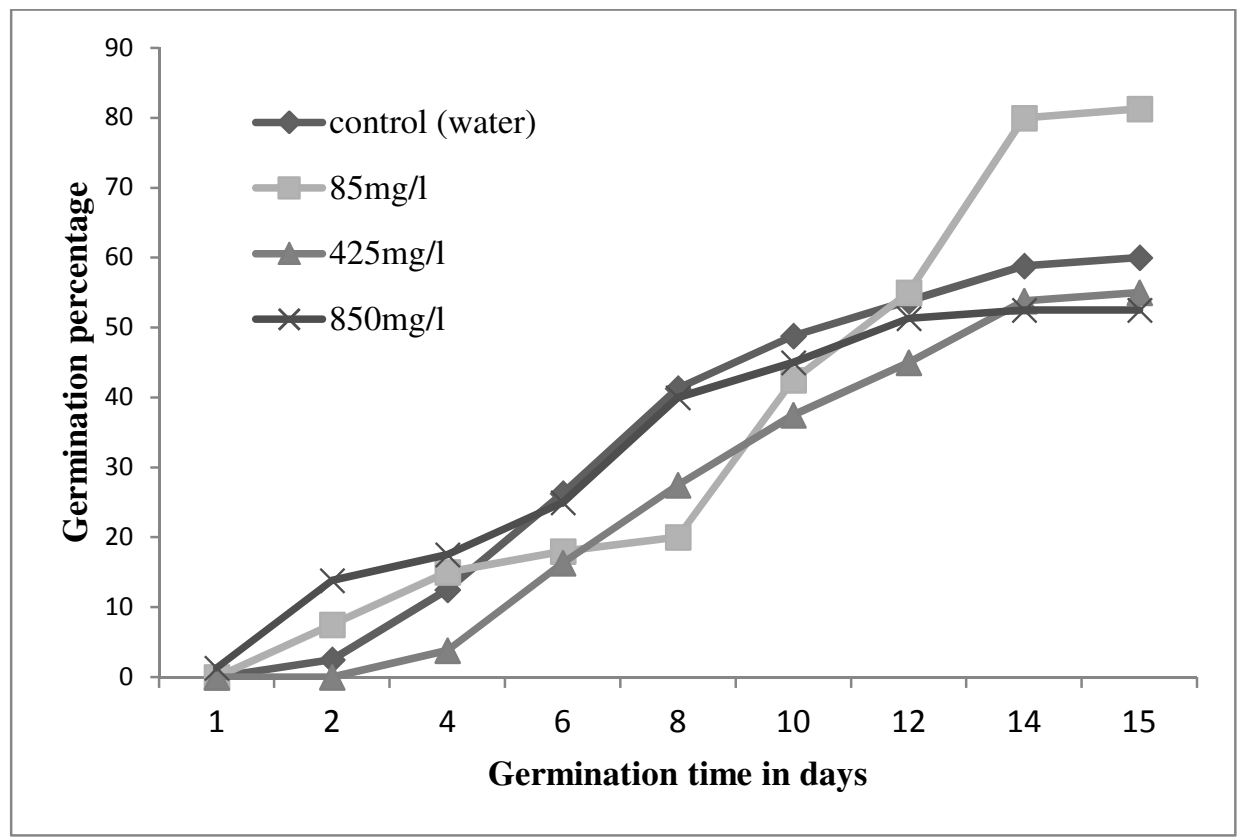

Fig.5: Germination response of seeds of $C$. frutescens to different concentrations of potassium nitrite germinated at $30^{\circ} \mathrm{C}$

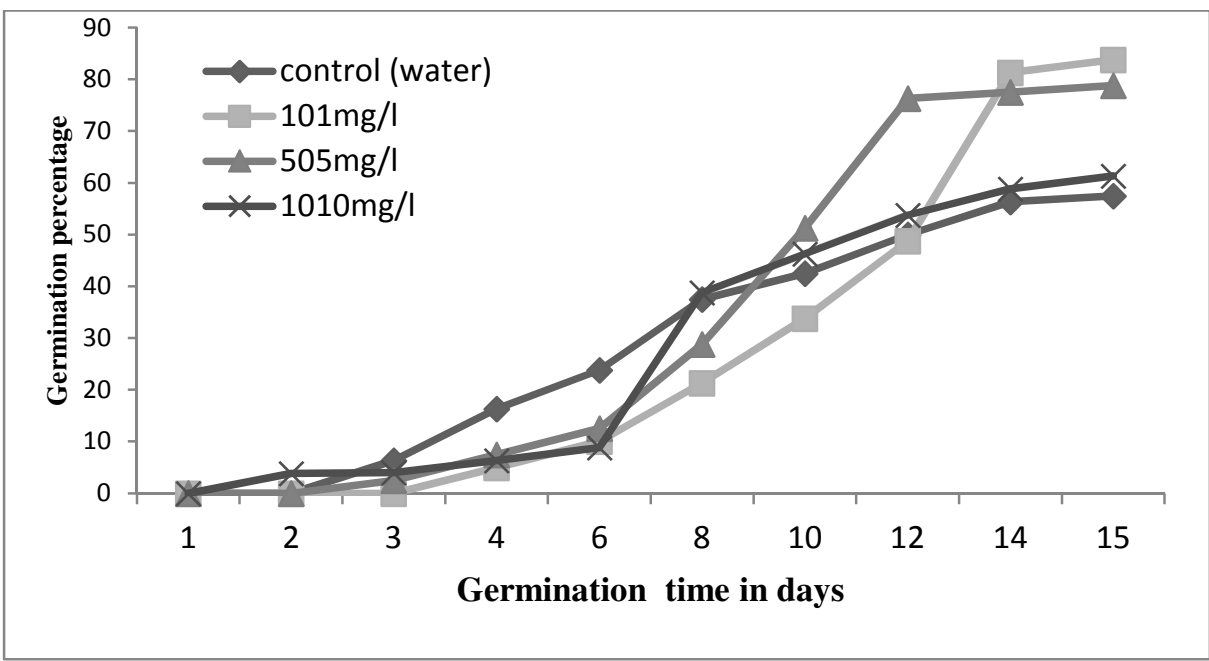

Fig.6: Germination response of $C$. frutescens seeds to different concentrations of Potassium nitrate germinated at $30^{\circ} \mathrm{C}$

Conclusion/Recommendation: Seed germination of Capsicum frutescens can be enhanced by treatments such as washing of the seeds, dry storage at room temperature, incubations in $\mathrm{GA}_{3}$, kinetin, $\mathrm{KNO}_{2}$ and $\mathrm{KNO}_{3}$. For optimum and increased production of the seeds of $C$. frutescens, it is recommended that seeds be grown in soils with low concentrations of $\mathrm{KNO}_{2}$ and $\mathrm{KNO}_{3}$ or soils enriched with these nitrogenous compounds in view of the challenges affecting the seed germination and its huge economic, medicinal and agricultural potentials.

\section{REFERENCES}

Ado, S.G. (1987). Capsicum in Nigeria. Germplasm Newsletter 1. Plant Genetic Resources Centre (PGRC/ILCA), Ibadan, Nigeria. 
Ajiboye, A.A. (2010). Dormancy and Seed Germination in Tamarindus indica (L.) The Pacific Journal of science and Technology, 11(2), 463-470.

Akman, Z. (2009). Effects of GA and kinetin presowing treatments on seedling emergence and seedling growth in wheat under saline conditions. J. Anim. Vet. Adv. 8:362-367.

Al-Menaie, H.S., Al-Ragam, O., Al-Shatti, A., Mathew, M., and Suresh, N. (2010). The effects of different treatments on seed germination of the Cassia fistula L. and Cassia nodosa buch.-Ham. exRoxb. In Kuwait. African Journal of Agricultural Research, 5(3), 230-35.

Argerich, C.A., Bradford, K.J. (1989). The effects of priming and ageing on seed vigour in tomato. $J$. Expt. Bot. 40:599-607.

Bewley, J.D.; Bradford, K.J. Hilhorst, K.H.W.M; Nonogaki, H. (2013). Seeds: Physiology of development germination and dormancy. New York: Springer, 392p.

Bhatnagar, V.K. and G.R. Rastogi (1980). Effect of some growth regulators on Zea mays. Geobios 7: 183-184.

Boonkird, s. Phisalaphong, C. Phisalaphong, M. (2008). Ultrasound-assisted extraction of capsaicinoids from Capsicum frutescens on a laband pilot-plant scale. Ultrason. Sonochem. 15: 1075-1079.

Bush, E.W., Wilson, P., Shepard, D.P., McClure, G. (2000). Enhancement of seed germination in common carpetgrass and centipede grass seed. Hort Science 35:769-770.

Davies, P.J. (1994). Plant hormones: Their role in plant growth and development. (2 ed.) New York: Nijhoff Publishers, P. 678.

Dolor, D.E. (2013): Propagation of Treculia africana as influenced by seed storage and propagation media. Agricultura. Tropical at subtropica 42/2, 52-57. 2013. Versita DOI 10,2478/ats-2013-009.

Edwards, R.L., Sundstrom, F.J. (1987). After ripening and harvesting effects on Tabasco pepper seed germination performance. Hort Science, v. 22, n. 3, p.473-475.
Esashi, Y.Y., Ohhara, M. And Okazaki, K.H. (1979). Control of cocklebur seed germination by nitrogenous compound; potassium nitrate hydroxylamine, thiourea, azide and cyanide. Plant Cell Physiol., 20: 349-361.

Evenari, N. (1965). Physiology of Seed Dormancy, After-ripening and Germination. Proc. Inst. Seed Test. Association, Vol. 30, 49-71.

Fialho, M.B., Toffano, L., Pedroso, M.P., Augusto, F., Pascholati, S.F. (2010). Volatile organic compounds produced by Saccharomyces cerevisiae inhibit the in vitro development of Guignardia citricarpa, the causal agent of citrus black spot. World journal of Microbiology and Biotechnology, v. 26, p. 925-932.

Gonalez, E. And Delsol, M.A. (1981). Induction of glyconeogenic enzymes by gibberellins $\mathrm{A}$, in endosperm of castor bean seedlings.plant Physiol, $67,550-554$.

Hedricks, S.B. and Taylorson, R.B. (1975). Breaking of Seed Dormancy by Catalase Inhibition. Proc. Natl. Acad. Sci. (USA) 72, 306-309.

Hsiao, A.I. (1979a). The effect of sodium hypochlorite and gibberellic acid on seed dormancy and germination of wild oats (Avena fatua L.) Can. J. Bot., 57:1729-1734.

Hsiao, A.I. (1979b). The effect of sodium hypochlorite, gibberellic acid, and light on seed dormancy and germination of wild buckwheat (Polygonum convolvulus) and cow cockle (Saponarina vacaria). Can. J. Bot., 57:17351739.

Idowu-Agida, O.O., Ogunniyan, D.J. and Ajayi, E.O. (2012). "Flowering and fruiting behaviour of long cayenne pepper (Capsicum frutescens L.)," International Journal of Plant Breeding and Genetics, vol. 6, no. 4, pp. 228-237.

Irfan, A., Fahad, M., Chaudhry, M.A., Shahzad, M.A.B., Amajad, H., and Fawad, S. (2013). Ethanol Priming: An Effective Approach to Enhance Germination and Seedling developmentby improving antioxidant system in Tomato Seeds. Acta Sci. Pol., Hortorum Cultus, 12(4), 129-137.

Jamil, M., Rha, E.S. (2007). Gibberellic acid (GA 3 ) enhance seed water uptake, germination and early seedling growth in sugar beet under salt stress. 
Pakistan Journal of Biological Sciences, V. 10, n. 4, p. 654-658.

Jeffrey, E.C. (2005). Environmental and Genetic Influence on the Germination of Arabidopsis taliana in the field. Evolution 59:4740.

Joshi, R.K., Mishra, S.D. and Gaur, B.K. (1987). Release of dormancy in Trombay groundnut seeds by plant growth regulators, Acta Botanica Indica 6:7-15.

Junttila, O. And Nilsen, A. (1980). Stimulation of Phalaris seed Germination by Respiratory Inhibitors and oxidizing Agents. Z. Pflanzen., 97, 429-435.

Kaur, S., Gupta, A.K., Kaur, N. (1998). Gibberellin $\mathrm{GA}_{3}$ reverses the effect of salt stress in chickpea (Cicer arietinum L.) seedlings by enhancing amylase activity and mobilization of starch in cotyledons. Plant Growth Regul. 26:85-90.

Ketring, D.L. and P.W. Morgan (1971). Physiology of oil seeds II. Dormancy release in Virginia type peanut seeds by plant growth regulators. Plant. Physiol. 47: 488-492.

Kirtikar, K.R. and Basu, B.D. (1980). Indian medicinal Plants, Published by Singh B and Singh M.P., India, pp. 800-805.

Lakon, G. (1949). The topographical tetrazolium method for determining the germinating capacity of seeds. Plant Physiol. 24:389-394.

Madakadze, R., Chirco, E.M., Khan, A.A. (1993). Seed germination of three flower species following matriconditioning under various environments. J. Ameri. Soc. Hort. Sci. 118:330334.

Marcos-Filho, J. (2005). Seed Physiology of cultivated plants. 1 ed. Piracicaba/SP: Fundacao de Estudos Agrarios "Luiz de Queiroz", v. 1 495p.

Mayer, A.M. and Poljakoff-Mayber, A. (1989). The Germination of seeds, $4^{\text {th }}$ edn. Pergamon Press, Oxford.

Mayer, A.M. and Poljakoff-mayer, A. (ed). (1982). The Germination of seeds ( $3^{\text {rd }}$ edition) Pergamon Press, Oxford.

McDonald, M.B. (2000). In Seed technology and its biological basis, seed priming, eds Black M., Bewley J.D. (Sheffield Academic Press Ltd., Sheffield, U.K.) pp. 287-325.
Mehta, P.M., M.T. Jacob and B.V.N. Rao (1978). The effects of ascorbic acid, kinetin, coumarin and their combination on the germination, growth and enzyme catalase of Cajanus cajan var. Selection 4-1A. Geobios 1:53-59.

Menichini, F., Tundis, R. Bonesi, M. Loizzo, M.R. Conforti, F. Statti, G., De Cindio B., Houghton, P.J. and Menichini, F. (2009). The influence of fruit ripening on the phytochemical content and biological activity of Capsicum chinense Jacq. Cv Habanero. Food Chemistry, 114: 553-560.

Mohammed Ahma (207). Physiological aspects of mungbean plant (Vigna radiate L. wilczek in response to salt stress and gibberellic acid treatment. Res. J. Agric. Biol. Sci. 3:200-213.

Nutile, G. (1945). Inducing dormancy in Lettuce Seed with Coumarin. Plant Physiology, 20, 433-442.

Nzegbule, E.C. and Mbakwe, R. (1999). Influence of gibberellic acid $\left(\mathrm{GA}_{3}\right.$ on early growth of nauclea didderichi. JSAE, 1: 16-117.

Oboth, G., Rocha, J.B.T. (2007). Distribution and antioxidant activity of polyphenols in ripe and unripe tree pepper (Capsicum pubescens). Journal of Food Biochemistry 31:456-473.

Onofeghara, F.A. (1981). The effects of growth substances on the flowering and fruiting of Lycopersicum esculentum and Vigna unguiculata. Phytol., 40 (1): 107-116.

Paleg, L.G. (1965). Physiological effects of Gibberellins. Ann Rev. Plant Physiol. 16, 291322.

Radley, M. (1967). Site of production of gibberellins - like substances in germinatingbarley embryos. Planta, 75, 164-171.

Ramamoorthy, K., Rajendran, C., and Sivasubramanian, S. (2005). Seed treatment for alleviation of hard seededness in senna (Cassia angustifolia L.). Adv. Plant Sci., 18(1), 429-430.

Roberts, E.H. (1973). Oxidation processes and the control of seed germination. In: Heydecker, W. (ed.) Seed Ecology. Butterworth, London, pp. 189-218

Roberts, e.H. (1973). Oxidative Processes and the control of Seed Germination. In: Seed Ecology (ed. W. Heydecker). London, Butterworth and Co Ltd., 189-217. 
Tambari, U., and Aminu, A.M. (2015). Effect of Different Seed Treatment Methods on the Germination of Senna obtusifolia in Sudan Savanna Ecosystem, Nigeria. American Academic and Scholarly Research Journal, 7(2). Retrieved from https://www.questia.com/library/journal/1P33649122401.

Toyomasu, T. Yamane, H. Murofushi, N. Inoue Y. (1994). Effects of exogenously applied gibberellins and red light on the endogenous levels of abscisic acid in photoblastic lettuce seeds. Plant Cell Physiol. 35:127-129.
Van Staden, J. Davey, J.E. and Brown, N.A.C. (1982). Cytokinin in Seed development and germination. The physiology and biochemistry of seed development, dormancy and germination. A.A. Khan. Ed () Elsevier Biomedical Press, 1982.

Zhuang, Y. Chen L., Sun, L. Cao, J. (2012). Bioactive characteristics and antioxidant activities of nine peppers. J. Funct. Foods. 4:331-338.

Zimmer, A.R., Leonardi, B., Miron, d. Schapoval, E., Oliveira, J.r. Gosmann, G. (2012). Antioxidant and anti-inflammatory properties of Capscium bacatum: from traditional use to scientific approach. J. Ethnpharmacol. 139:228-233. 